\title{
Physiological and clinical aspects in COVID-19
}

\author{
Satyanath R. Kodidala ${ }^{1}$, J. Sorout ${ }^{1}$, S. Jayachandra ${ }^{2}$, A. Gandhi ${ }^{3}$, S. Kacker ${ }^{4}$ \\ ${ }^{1}$ Kanti Devi Medical College, Hospital and Research Centre, Mathura, India. \\ ${ }^{2}$ Zydus Medical College and Hospital. Dahod, Gujarat, India. \\ ${ }^{3}$ Faculty of Medicine and Health Science. S.G.T University, Budhera, Gurgram, India. \\ ${ }^{4}$ RUHS College Of Medical Science, Jaipur, India.
}

\begin{abstract}
There is a new public health crises threatening globally with the emergence and spread of 2019 novel corona virus (COVID-19) or the severe acute respiratory syndrome corona virus 2 (SARS-CoV-2). In very recent decade we have seen endemic outbreaks in the form of Middle East respiratory syndrome coronavirus (MERS CoV) and severe acute respiratory syndrome related coronavirus (SARS-CoV). Now we again see the emergence of another serious outbreak due to a new strain called the SARS-CoV-2 virus. This SARS-CoV-2 initially presented as pneumonia of unknown etiology with group of symptoms including fever, dry cough and shortness of breath in a cluster of patients in December 2019 Wuhan, China. COVID-19 now has quickly became a health emergency now across worldwide. SARS-CoV-2 is a newly emerging human infectious corona virus that causes COVID-19, now this has been recognized as a pandemic by the World Health Organization (WHO) on $11^{\text {th }}$ March, 2020. Because of the pathogenesis and proliferation pathways of COVID-19 are still unknown the development of vaccine was not developed yet and definitive treatment was not implemented. Therefore, in this article, new potential COVID-19 therapies are briefly reviewed. The world is in emergent need for searching of possible medications for COVID-19.
\end{abstract}

Keywords: Corona virus, COVID-19, MERS CoV, SARS-CoV, Therapies

Contribution of the authors. Dr. Satyanath Reddy Kodidala, Dr. Jitender Sorout and Dr. Srinivasa Jayachandra contributed the study concept, design and drafting of manuscript. Dr. Asha Gandhi and Dr. Sudhanshu Kacker have done the critical revision and final approval of manuscript.

Conflict of interest statement. The authors declare no conflict of interest.

Received 11.052020. Accepted 06.06.2020

For citation: Satyanath R. Kodidala, J. Sorout, S. Jayachandra, A. Gandhi, S. Kacker. Physiological and clinical aspects in COVID-19. RUDN Journal of Medicine. 2020; 24 (3): 201-206. DOI: 10.22363/2313-0245-2020-24-3-201-206

(c) Satyanath R. Kodidala, J. Sorout, S. Jayachandra, A. Gandhi, S. Kacker, 2020 


\title{
Физиологические и клинические аспекты COVID-19
}

\author{
Сатьянатх Р. Кодидала ${ }^{1}$, Дж. Сороут ${ }^{1}$, С. Джаячандра ${ }^{2}$, А. Ганди ${ }^{3}$ С. Кэкер ${ }^{4}$ \\ ${ }^{1}$ К.Д. Медицинский колледж, клиника и исследовательский центр, г. Матхура, Индия \\ ${ }^{2}$ Медицинский колледж Зидус, г. Даход, Гуджарат, Индия \\ ${ }^{3}$ Университет Шри Гуру Гобинд Сингх, г. Будера, Гурграм, Индия \\ ${ }^{4}$ Медицинский колледж Рухс, г. Джайпур, Индия
}

\begin{abstract}
Аннотация. В мире возник новый кризис в области общественного здравоохранения, угрожающий появлением и распространением нового коронавируса 2019 г. (COVID-19), или коронавирусного тяжелого острого респираторного синдрома 2 (SARS-CoV-2). В последнее десятилетие мы наблюдали эндемические вспышки в виде коронавируса ближневосточного респираторного синдрома (MERS CoV) и коронавируса тяжелого острого респираторного синдрома (SARS-CoV). Теперь мы снова видим появление еще одной серьезной вспышки из-за нового штамма под названием вирус SARS-CoV-2. Этот вирус SARS-CoV-2 первоначально был представлен как пневмония неизвестной этиологии с симптомами, включающими жар, сухой кашель и одышку в группе пациентов в декабре 2019 в г. Ухань, Китай. COVID-19 быстро стал причиной чрезвычайной ситуации в области здравоохранения во всем мире. SARS-CoV-2 - это недавно появившийся коронавирус, вызывающий инфекцию человека, COVID-19, которую Всемирная организация здравоохранения (BO3) 11 марта 2020 года признала пандемией. Патогенез и пути распространения COVID-19 до сих пор неизвестны, разработка вакцины еще не завершена, и способ лечения не найден. Таким образом, в этой статье кратко рассматриваются новые потенциальные способы терапии COVID-19. Мир остро нуждается в поиске возможных лекарств от COVID-19.
\end{abstract}

Ключевые слова: коронавирус, COVID-19, MERS CoV, SARS-CoV, терапия

Вклад авторов. Доктор Сатьянатх Редди Кодидала, доктор Джитендер Сороут и доктор Шриниваса Джаячандра внесли свой вклад в концепцию исследования, дизайн и составление рукописи. Доктор Аша Ганди и доктор Судханшу Кэкер сделали критический пересмотр и окончательное утверждение рукописи.

Заявление о конфликте интересов. Авторы заявляют об отсутствии конфликта интересов.

Поступила 11.05.2020. Принята 06.06.2020.

Для цитирования: Сатьянатх Р. Кодидала, Сороут Дж., Джаячандра С., Ганди А., Кэкер С. Физиологические и клинические аспекты COVID-19 // Вестник Российского университета дружбы народов. Серия: Медицина. 2020. T. 24. № 3. C. 201-206. DOI: 10.22363/2313-0245-2020-24-3-201-206

\section{Introduction}

Novel coronavirus (2019-nCoV), officially known as severe acute respiratory syndrome coronavirus 2 (SARS-CoV-2), the etiological agent (Corona Virus Disease 2019) COVID-19 was emerged in Wuhan city, Hubei province of China in December, 2020. On 11th March 2020, The World Health Organization (WHO) declared this disease as pandemic [1]. Despite with drastic containment measures, the COVID-19 outbreak has taken lives of people almost more than 1,20,437 number worldwide, with the number of those contracting the virus surpassing 1,934,128 (as of April 14, 2020) [2]. India has reported 10,541 confirmed cases including 358 death cases till date (as of April 14, 2020) [3]. Fortunately so far, children was infrequently affected with almost very less or nil death rates. But the future course of this pandemic virus is still unknown to us. This review article gives a clear bird's eye view point about this new emerged pandemic virus as knowledge about this virus is rapidly evolving, readers who urges to update themselves regularly. 


\section{Methodology}

Relevant studies were identified and extracted by irrespective of time and a comprehensive search in database search engines namely Pub Med, Scopus, Science Direct and Google Scholar. Irrelevant studies were excluded in this review article. Terms were typed and searched as "COVID-19", "SARS-CoV-2" and "2019-nCOV” in titles, abstracts and keywords. After that, ongoing and completed clinical trials, clinical reports, case reports and suggestions for potential medications against treatment of COVID-19 were also briefly reviewed.

\section{Aetiology}

CoVs are positive-stranded RNA viruses with a crown-like appearance when looked under an electron microscope (coronam means crown in Latin) due to the presence of glycoprotein spikes on the envelope. The subfamily classifies into four genera of CoVs: Alphacoronavirus (alpha CoV), Betacoronavirus [(beta $\mathrm{CoV}$ ) further the betaCoV genus divides into five subgenera or lineages], Deltacoronavirus (delta CoV) and Gammacoronavirus (gamma CoV) [4]. Genomic data when analysed shown that most probably bats and rodents are the gene sources of alpha CoVs and beta CoVs while the avian species seem to represent the gene sources of deltaCoVs and gammaCoVs. Members of this large group of viruses can cause mainly respiratory problems also intestinal, hepatocellular and neurological diseases in different animal species. Till date, seven humanCoVs (HCoVs) are capable of infecting human beings have been identified so far. Some of HCoVs were identified in the mid-era 1960s, while others were detected in the recent new era. In general, data suggests that $2 \%$ of the human population are healthy carriers of a $\mathrm{CoV}$ and that these viruses are responsible for about $5 \%$ to $10 \%$ of acute respiratory infections in them [5]. Which is again dependent on the immunity of particular person. Ig M, the first antibody to be appear in the acute stage if SARS- CoV which can be detected within in three days which is recommended by diagnosis and treatment. Guidelines on Novel Corona virus Disease were formed for diagnosis.

The epidemiology of COVID-19: In December 2019, outbreak initially presented as pneumonia of unknown etiologic in a cluster of patients in Wuhan, China and now has quickly become a health emergency across worldwide. The number of cases started increasing exponentially, those who did not have any kind of exposure to the live animal market which suggests the fact that person-to-person transmission was occurring [6]. The first fatal case was reported on 11th Jan 2020 in china while massive migration of Chinese during the Chinese New Year fuelled the cause of epidemic. The first case of covid-19 pandemic in India was reported on 30 ${ }^{\text {th }}$ January-2020 and kept gradually rising. Keeping this point of view Indian prime minister Mr. Narendra Modi announced a voluntary curfew for public on $22^{\text {nd }}$ March 2020, further it was extended as lock down initially for 21 days from $24^{\text {th }}$ march and extended up to $3^{\text {rd }}$ May,2020. According to a study from Shiv Nadir University, India might have witnessed a massive spill of $31 \mathrm{k}$ cases of covid-19 victims between $24^{\text {th }}$ march and $14^{\text {th }}$ April without lockdown [7]. In India the spread of pandemic was under control due to lockdown by limiting person to person spread.

Pathophysiology of Covid-19: Glycoprotein spikes present on the envelope of covid-19 have the antigenic nature binds with the ACE-2 receptors present in respiratory system in humans [8, 9]. Some studies also suggested that the SARS- CoV2 uses the same pathway into cellular entry. After attaching with the ACE-2 receptors the viral genomic material RNA released into the cytoplasm of host cells. Then RNA translates the two proteins pp1a and pp1ab which forms replication transcription complex (RTC). Regularly RTC replicates and synthesise nested sub genomic RNAs which is responsible for production of accessory proteins and structured proteins components. Thus, formation of a new viral particle buds [10]. On the basis of previous studies done on other CoVs, especially SARS-CoV and MERS-CoV only the immunological responses can be explained. In general, at first after a virus enters into host either by exposed or cross contamination, it is first get recognized by the hosts innate immune system through pattern recognition receptors (PRRs) including C-type lectin-like receptors, Toll-like receptor (TLR), NOD-like receptor (NLR) and RIG-I like receptor (RLR) as well [11]. Then through different pathways, 
the virus induces the expression of inflammatory factors, maturation of dendritic cells and production of type I interferons (IFNs) which accelerates macrophage phagocytosis of viral antigens by limiting their spreading [11]. However, the $\mathrm{N}$ protein present in SARSCoV can help the virus escape from the exposure to immune responses in host as soon as adaptive immune response joins the fight against the viruses. While the CD4+ B and CD8+ T lymphocyte cells play an important role by stimulating CD4+ B cells produce virus-specific antibodies and CD8+ T cells directly kill virus-infected cells and produce pro inflammatory cytokines. However, $\mathrm{CoV}$ can inhibit functions of $\mathrm{T}$ cells by promoting apoptosis of T cells [12,13]. COVID-19 might affect only the human lungs because it is mainly a respiratory disease. The primary mode of infection is via spraying droplets from infected individual either by cough or sneeze from person-to-person transmission through close contact. COVID-19 most probably have asymptomatic incubation period between 2 and 14 days during which the virus can be highly transmitted [14]. With various clinical reports on SARS and MERS, the most common symptoms of COVID-19 are fever, severe fatigue, head ache, cough, diarrhoea and shortness of breath with other respiratory symptoms. In addition, when 41 hospitalized patients were analysed they founded with high-levels of pro inflammatory cytokines including IL-2, IL-7, IL-10, G-CSF, IP-10, MCP-1, MIP-1A and TNF $\alpha$ were observed in the COVID-19 severe cases [15]. This "cytokine burst" causing respiratory distress syndrome and may potentially leads to death. At present, the mortality rate of COVID-19 in India is approximately $3.4 \%$ which are caused by multi-system failure especially in elderly people.

\section{Present knowledge of treatment in COVID-19 patients}

No doubt antiviral and supportive treatments are very important in the treatment of patients with COVID-19. As cytokine burst is relatively common in severe cases and often leads to the exacerbation, anti-inflammation therapy may help in preventing further injury in such case. As we already know, there are a variety of anti-inflammatory medications, including non-steroidal anti-inflammatory drugs, glucocorticoids, chloroquine/ hydroxychloroquine, immunosuppressant's, inflammatory cytokines antagonists (such as IL-6R monoclonal antibodies, TNF inhibitors, IL-1 antagonists, Janus kinase inhibitors (JAKs) etc., Siddiqu and Mehra suggested that tailored therapy in stage III hinges on the use of immunomodulatory agents to reduce systemic inflammation primarily before it overwhelmingly results in multi-organ dysfunction. In this phase, use of corticosteroids may be justified in concern with the use of cytokine inhibitors such as tocilizumab (IL-6 inhibitor) or anakinra (IL-1 receptor antagonist). Intravenous immune globulin (IV Ig) may also play a role in modulating an immune system that is in a hyper inflammatory state. Overall, the prognosis and recovery from this critical stage of illness is poor, and prompt recognition and application of such therapy may have the greatest yield $[16,17]$.

At present, systemic glucocorticoids administration was empirically used for severe complications in order to suppress cytokine burst manifestations in patients with COVID-19, such as ARDS, acute heart injuries, acute kidney complication and also patients with higher D-dimer levels [18 - 20]. However, there is no evidence from randomized clinical trials to support the glucocorticoids treatment for COVID-19. Chen et al. reported 19 (19\%) patients were treated with glucocorticoids for 3-15 days (median 5 [18, 21—24]) and methyl prednisolone ( $1-2 \mathrm{mg} / \mathrm{kg}$ per day) are recommended for patients with ARDS, for as short as duration of treatment is possible [25].

\section{Conclusion from physiological point of view:}

Hence we conclude based on the available data that there was a strong binding between SARS-CoV-19 and ACE2 receptor causing respiratory distress in affected people. But as of now no specific antiviral treatment was recommended for COVID-19 and vaccine was not yet currently available. The treatment is completely symptomatic and oxygen therapy has major treatment intervention for patients with those having severe infection. We recommend as best of our knowledge ACE2 inhibitors in small doses can be given in infected and healthy population and drugs that inhibit S-protein ACE2 interaction. If this is followed the cytokine burst will be decreased and less chances of respiratory distress syndrome. So this would be definitely a precautionary step. 
As on the basis of previous studies on COVID-19 there was cytokine burst in people who affected with covid-19 pathogen. This was responsible for causing various respiratory breathing complications especially in elderly people and children due to low immunity levels and even causing morbidity.

From the available knowledge regarding the treatment of COVID-19 many studies suggested to boost up immune system while on other hand studies suggest glucocorticoids treatment to suppress cytokine activity to escape from these complications, antiviral drugs remdesivir and chloroquine are highly effective with safety track record and Lopinavir/ Ritonavir, Neuraminidase inhibitors, peptide (EK1), RNA synthesis inhibitors acting at cellular level in the control of COVID-19 pandemic infection which also leads to deteriotion of other systems in patients. Keeping in mind the guidelines implemented for treatment of COVID-19, we think that use of chloroquine and hydroxychloroquine along with immunity boosters will be a positive outcome in people affected with COVID-19 with minimal complications. These suggestions can be viewed and might be useful in the effective treatment of COVID-19 infection.

\section{References/ Библиографический список}

1. Zhou P., Yang X.L., Wang X.G., Hu B., Zhang L., Zhang W., et al. Discovery of a novel coronavirus associated with the recent pneumonia outbreak in humans and its potential bat origin. BioRxiv. 2020.

2. Coronavirus Outbreak. Available at: https://www.worldometers. info/ coronavirus Accessed 14, April 2020.

3. https://www.worldometers.info/coronavirus/\#countries. Accessed 14, April 2020.

4. Chan J.F., To K.K., Tse H., Jin D.Y., Yuen K.Y. Interspecies transmission and emergence of novel viruses: lessons from bats and birds. Trends Microbiol. 2013 Oct; 21(10):544—55.

5. Chen Y., Liu Q., Guo D. Emerging coronaviruses: Genome structure, replication, and pathogenesis. J. Med. Virol. 2020 Apr;92(4):418-423.

6. World Health Organization. Situation reports. Available at: https:// www.who.int/emergencies/diseases/novel-coronavirus-2019/ situation-reports/. Accessed 22 Feb 2020.

7. Sagar Kulkarni (3 April 2020). «India would have seen 31,000 coronavirus cases without lockdown: Researches». Deccan Herald. Retrieved 4 April 2020.

8. Wan Y., Shang J., Graham R., Baric R.S., Li F. Receptor recognition by novel coronavirus from Wuhan: an analysis based on decade-long structural studies of SARS. J Virol. 2020. https:// doi.org/10.1128/JVI.00127—20

9. Tortorici M.A., Veesler D. Structural insights into coronavirus entry. Adv Virus Res. 2019;105:93-116.

10.Perrier A., Bonnin A., Desmarets L., Danneels A., Goffard A., Rouille Y., et al. The C-terminal domain of the MERS coronavirus M protein contains a trans- Golgi network localization signal. J Biol Chem. 2019; 294(39):14406-21.

11. Ben Addi A., Lefort A., Hua X., Libert F., Communi D., Ledent C., et al. Modulation of murine dendritic cell function by adenine nucleotides and adenosine: involvement of the A(2B) receptor. European journal of immunology. 2008; 38: 1610-20.

12. Mathern D.R., Heeger P.S. Molecules Great and Small: The Complement System. Clin J Am Soc Nephrol. 2015; 10: 1636-50.

13. Traggiai E., Becker S., Subbarao K., Kolesnikova L., Uematsu Y., Gismondo M.R., et al. An efficient method to make human monoclonal antibodies from memory B cells: potent neutralization of SARS coronavirus. Nat Med. 2004; 10:871—5.

14. Center for Disease Control and Prevention [Internet]. Atlanta: CDC; c2020 [cited 2020 April, 14]. Symptoms of Novel Coronavirus (2019-nCoV); [about 1 screen]. Available from: https://www.cdc. gov/coronavirus/2019-ncov/ about/symptoms.html.

15.Huang C., Wang Y., Li X., Ren L., Zhao J., Hu Y., et al. Clinical features of patients infected with 2019 novel corona virus in Wuhan, China. Lancet. 2020; 395:497-506.

16. Siddiqi H.K., Mehra M.R. COVID-19 illness in native and immune suppressed states: a clinical-therapeutic staging proposal. J. Heart Lung Transplant. 2020. 39(5): 405—407.

17.Chen C., Zhang X.R., Ju Z.Y., He W.F. Advances in the research of cytokine storm mechanism induced by Corona virus disease 2019 and the corresponding immunotherapies. Chin. J. Burns. 2020 Mar 01; 36(0): E005.

18. Huang C., Wang Y., Li X., Ren L., Zhao J., Hu Y. Clinical features of patients infected with 2019 novel coronavirus in Wuhan, China. Lancet. 2020; 395:497-506.

19. Sun P., Lu X., Xu C., Sun W., Pan B. Understanding of COVID-19 based on current evidence. J. Med. Virol. 2020 Mar 5: 10.1002/ jmv.25722.

20.Chan K.W., Wong V.T., Tang S.C.W. COVID-19: an update on the epidemiological, clinical, preventive and therapeutic evidence and guidelines of integrative Chinese-Western medicine for the management of 2019 novel coronavirus disease. Am.J. Chin. Med. 2020:1-26.

21.Conti P., Ronconi G, Caraffa A, Gallenga C.E, Ross R, Frydas I. Induction of pro-inflammatory cytokines (IL-1 and IL-6) and lung inflammation by Coronavirus-19 (COVI-19 or SARSCoV-2): anti-inflammatory strategies. J. Biol. Regul. Homeost. Agents. 2020 Mar 14;34(2):1. doi: 10.23812/CONTI-E.

22.Zhou F., Yu T., Du R., Fan G., Liu Y., Liu Z. Clinical course and risk factors for mortality of adult in patients with COVID-19 in Wuhan, China: a retrospective cohort study. Lancet. 2020 Mar 28;395(10229):1054_1062. doi: 10.1016/S0140_ 6736(20)30566-3.

23. Ruan Q., Yang K., Wang W., Jiang L., Song J. Clinical predictors of mortality due to COVID-19 based on an analysis of data of 150 patients from Wuhan, China. Intensive Care Med. 2020; 
46:846-848.

24. Chen N., Zhou M., Dong X., Qu J., Gong F., Han Y. Epidemiological and clinical characteristics of 99 cases of 2019 novel coronavirus pneumonia in Wuhan, China: a descriptive study. Lancet. 2020;395:507-513.
25. Chen N., Zhou M., Dong X., Qu J., Gong F., Han Y. Epidemiological and clinical characteristics of 99 cases of 2019 novel coronavirus pneumonia in Wuhan, China: a descriptive study. Lancet. 2020;395:507-513.

Corresponding author: Satyanath R. Kodidala — Assistant Professor, Department Of Physiology, K.D Meical College, Hospital And Research Centre. Mathura, 281406, India, Email: ksatyanath1989@gmail.com

Satyanath R. Kodidala ORCID: 0000-0001-7830-7211

Sorout J. ORCID: 0000-0002-1510-0982

Jayachandra S. ORCID: 0000-0001-9473-8011

Gandhi A. ORCID: 0000-0001-7461-3318

Kacker S. ORCID: 0000-0001-7830-7211

Ответственный за переписку: Сатьянатх Р. Кодидала — доцент кафедры физиологии, К.Д. Медицинский колледж, Больница и исследовательский центр. Матхура, 281406, Индия, электронная почта: ksatyanath1989@gmail.com

Сатьянатх P. Кодидала ORCID: /0000-0001-7830-7211

Сороут Дж. ORCID: 0000—0002-1510—0982

Джаячандра C. ORCID: 0000—0001—9473—8011

Ганди A. ORCID: 0000—0001-7461—3318

Кэкер C. ORCID: /0000—0001—7830-7211 